\title{
Chemical Diversity of Panax ginseng, Panax quinquifolium, and Panax notoginseng
}

\author{
Dong-Hyun Kim* \\ Department of Life and Nanopharmaceutical Sciences and Department of Pharmaceutical Science, Kyung Hee University, \\ Seoul 130-701, Korea
}

The major commercial ginsengs are Panax ginseng Meyer (Korean ginseng), P. quinquifolium L. (American ginseng), and $P$. notoginseng (Burk.) FH Chen (Notoginseng). P. ginseng is the most commonly used as an adaptogenic agent and has been shown to enhance physical performance, promote vitality, increase resistance to stress and aging, and have immunomodulatory activity. These ginsengs contain saponins, which can be classified as dammarane-type, ocotillol-type and oleanane-type oligoglycosides, and polysaccharides as main constituents. Dammarane ginsenosides are transformed into compounds such as the ginsenosides $\mathrm{Rg}_{3}, \mathrm{Rg}_{5}$, and $\mathrm{Rk}_{1}$ by steaming and heating and are metabolized into metabolites such as compound $\mathrm{K}$, ginsenoside $\mathrm{Rh}_{1}$, protoand panaxatriol by intestinal microflora. These metabolites are nonpolar, pharmacologically active and easily absorbed from the gastrointestinal tract. However, the activities metabolizing these constituents into bioactive compounds differ significantly among individuals because all individuals possess characteristic indigenous strains of intestinal bacteria. To overcome this difference, ginsengs fermented with enzymes or microbes have been developed.

Keywords: Panax ginseng, Panax quinquifolium, Panax notoginseng, Constituents, Biotransformation

\section{INTRODUCTION}

The term ginseng refers to the dried roots of several plants of the species Panax sp. (Family Araliaceae). The three major commercial ginsengs are $P$. ginseng Meyer (Korean ginseng), which has been used as an herbal medicine for more than 2000 years [1], P. quinquifolium L. (American ginseng), and P. notoginseng (Burk.) FH Chen (Notoginseng) [2,3]. These ginsengs have been used worldwide for thousands of years as either food or herbal medicines. $P$. ginseng has been the most commonly used as an adaptogenic agent and has been shown to enhance physical performance, promote vitality, increase resistance to stress and aging, and have immunomodulatory activity $[4,5]$.

The roots of these ginsengs have been used as herbal

(c) This is an Open Access article distributed under the terms of the Creative Commons Attribution Non-Commercial License (http://creativecommons.org/licenses/by-nc/3.0/) which permits unrestricted non-commercial use, distribution, and reproduction in any medium, provided the original work is properly cited. medicines in Asian countries, and their bioactive chemicals have been isolated. In 1854, Garriques performed the first chemical studies on ginseng [6] and separated a saponin fraction from $P$. quinquifolium. Despite these findings, the components of ginseng were not studied again until 1963. Shibata et al. [7], Shibata et al. [8], and Shibata et al. [9] isolated ginseng saponins from the root of $P$. ginseng and identified their structures in 1963. These saponins were called ginsenosides. Since the reports of Shibata et al., many researchers have isolated the components of Korean ginseng, American ginseng, and Notoginseng. Today, approximately 200 substances, such as ginsenosides, polysaccharides, polyacetylenes, peptides, and amino acids, have been isolated from Korean gin-

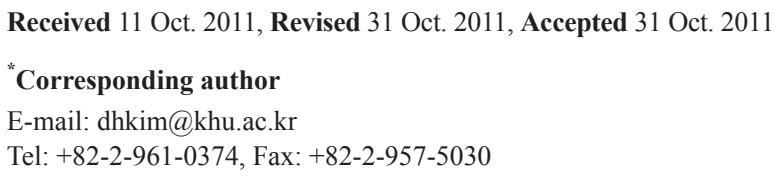




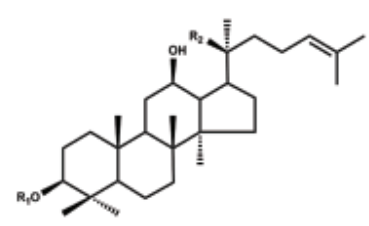

PPD

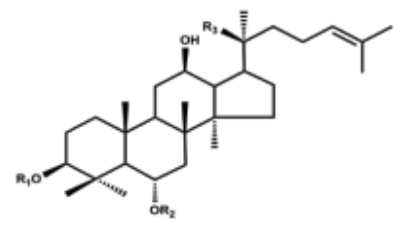

PPT

$\begin{array}{lll} & \mathrm{R} 1 & \mathrm{R} 2 \\ \text { Ginsenoside } \mathrm{Rb}_{1} & \text { Glc-glc- } & \text { Glc-glc-O- } \\ \text { Ginsenoside Rd } & \text { Glc-glc- } & \text { Glc-O- } \\ \text { Ginsenoside } \mathrm{Rg}_{3} & & \text { HO- } \\ \text { Ginsenoside } \mathrm{Ra}_{3} & \text { Glc-glc- } & \text { Xyl-glc-glc- } \\ \text { Ginsenoside } \mathrm{Rh}_{2} & \text { Glc- } & \text { HO- } \\ \text { Compound } \mathrm{K} & \mathrm{H} & \text { Glc-O- } \\ \text { 20S-protopanaxadiol } & \mathrm{H} & \text { HO- }\end{array}$

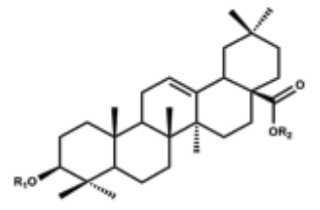

Oleanane

$\begin{array}{lllll} & \text { R1 } & \text { R2 } & & \text { R } \\ \text { Ginsenoside Ro } & \text { GlcA-glc- } & \text { Glc- } & \text { Majonoside R2 } & \text { Xyl-glc- } \\ \text { Chikusetsusaponin IVa } & \text { GlcA- } & \text { Glc- } & \text { Pseudoginsenoside RTt5 } & \text { Glc- }\end{array}$

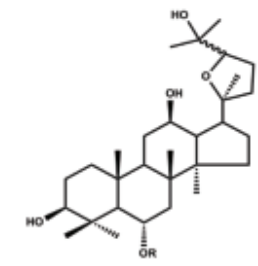

Octotillol

$\begin{array}{llll}\text { Ginsenoside } \mathrm{Re} & \mathrm{H} & & \\ \text { Ginsenoside } \mathrm{Rg}_{1} & \mathrm{H} & \text { Glc- } & \text { Glc-O- } \\ \text { Ginsenoside } \mathrm{Rf} & \mathrm{H} & \text { Glc-glc- } & \text { HO- } \\ \text { Ginsenoside } \mathrm{Rh}_{1} & \mathrm{H} & \text { Glc- } & \text { HO- } \\ \text { Notoginsenoside R1 } & \mathrm{H} & \text { Xyl-glc- } & \text { Glc-O- } \\ \text { Gisnenosdie } \mathrm{F} 1 & \mathrm{H} & \mathrm{H} & \text { Glc-O- } \\ \text { 20S-protopanaxatriol } & \mathrm{H} & \mathrm{H} & \mathrm{OH}\end{array}$

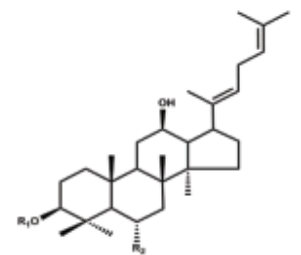

Modified PPD and PPT

$\begin{array}{llllll} & \text { R1 } & \text { R2 } & & \text { R1 } & \text { R2 } \\ \text { Ginsenoside Rk } & \text { Glc-glc- } & \text { H- } & \text { Ginsenoside } \mathrm{Rg}_{5} & \text { Glc-glc- } & \text { H } \\ \text { Ginsenoside } \mathrm{Rk}_{2} & \text { Glc- } & \text { H } & \text { Ginsenoside } \mathrm{Rh}_{3} & \text { Glc- } & \text { H } \\ \text { Ginsenoside Rk } & \text { H } & \text { Glc-O- } & \text { Ginsenoside } \mathrm{Rh}_{4} & \mathrm{H} & \text { Glc-O- }\end{array}$
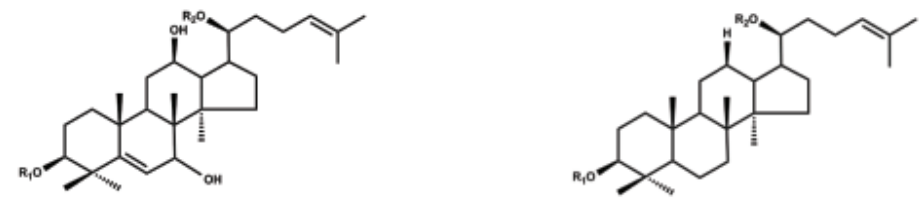

Modified ginsenoside

$\begin{array}{llllll} & \text { R1 } & \text { R2 } & & \text { R1 } & \text { R2 } \\ \text { Quinquinoside IV } & \text { Glc-glc- } & \text { Glc-glc- } & \text { Vina-ginsenoside R3 } & \text { Glc-glc- } & \text { Glc- } \\ \text { Notoginsenoside G } & \text { Glc-glc } & \text { Glc- } & & & \end{array}$

Fig. 1. The structures of representative ginseng saponins. PPD, protopanaxadiol; PPT, protopanaxatriol. 
seng [2], and more than 100 substances have been isolated from American ginseng and Notoginseng. Among the substances isolated from ginseng, the major and most unique components are the ginseng saponins (ginsenosides), which can be classified as dammarane-type, ocotillol-type and oleanane-type oligoglycosides (Fig. 1), and polysaccharides [10]. Furthermore, the dammaranetype saponins are classified into protopanaxadiol and protopanaxatriol types. The protopanaxadiol-type has sugar moieties attached to $\mathrm{OH}$ at $\mathrm{C}-3$ and/or C-20, and the protopanaxatriol-type has sugar moieties attached to $\mathrm{OH}$ at C-3, C-6, and/or C-20. The ocotillol-type has a fivemembered epoxy ring at C-20, and the oleanane-type has a modified C-20 side chain. With the development of instrumental analysis, minor constituents are constantly being isolated from these ginsengs.

Chemically, several differences exist among Korean ginseng, American ginseng, and Notoginseng. An important parameter used for differentiation is the presence of the ginsenoside $\mathrm{Rf}$ in Korean ginseng and Notoginseng, the pseudoginsenoside F11 in American ginseng [11], and the notoginsenoside R1 in Korean ginseng and Notoginseng. In addition, the ratio of $\mathrm{Rg}_{1} /$ $\mathrm{Rb}_{1}$ has been widely used to differentiate between these ginsengs. Ratios of less than 0.4 are indicative of American ginseng, whereas a high value ratio is characteristic of Korean ginseng and Notoginseng [12]. Although notoginsenosides are not isolated from the root of Korean ginseng, many notoginsenosides are found in Notoginseng (Table 1).

Recent studies have reported the constituents of the roots of Korean ginseng, American ginseng and Notoginseng as well as their leaves and stem, flower buds, and fruits. Based on these findings, the leaves and stem, flower buds, fruits, and roots have recently been used as functional food, cosmetics, and herbal medicines. Furthermore, immunopotentiating polysaccharides have been isolated from these ginsengs. Acidic polysaccharides are more abundant in Korean ginseng compared with those in American ginseng and Notoginseng. However, the structures of many polysaccharides that are isolated from ginsengs have not been clearly identified.

\section{CHEMICAL DIVERSITY OF PANAX GINSENG}

Today, approximately 200 substances, such as ginsenosides, polysaccharides, polyacetylenes, peptides, and amino acids, have been isolated from Korean ginseng [2]. Of these, ginsenosides and polysaccharides are the major and most unique constituents.

\section{Saponins}

Saponins are the major constituents isolated from the root of Korean ginseng. Because $P$. ginseng has been historically used as an herbal medicine, extensive chemical studies have focused on the root of $P$. ginseng. Recent studies are focusing on the constituents of the leaves and stem, flower buds, fruits, and roots of ginseng and their pharmacological activities. Since Shibata et al. isolated prosapogenins in 1963, many kinds of saponins have been isolated from its roots, leaves and stem, flower buds, fruits, and seeds. Shibata et al. [7] established the chemical structures of main the prosapogenins 20Sprotopanaxadiol, 20S-protopanaxatriol, prosapgenin, and ginsenoside $\mathrm{Rg}_{1}$, which were extracted from the dried root of ginseng [8,9,13]. Kitagawa et al. [14] and Kitagawa et al. [15] isolated malonyl ginsenosides $R b_{1}, R_{2}$, $\mathrm{Rc}$, and Rd from the dried root of ginseng. Subsequently, the ginsenosides Ro, $\mathrm{Ra}_{1}, \mathrm{Ra}_{2}, \mathrm{Ra}_{3} \mathrm{Re}, \mathrm{Rf}, \mathrm{Rg}_{1}, \mathrm{Rg}_{2}, \mathrm{Rg}_{3}$, $\mathrm{Rh}_{1}$, the notoginsenosides $\mathrm{R} 4,20$-gluco-ginsenoside $\mathrm{Rf}$, koryoginsenoside $\mathrm{R} 1$, and $\mathrm{R} 2$, and the ginsenosides $\mathrm{Rb}_{1}$, $\mathrm{Rb}_{2}, \mathrm{Rc}$, and $\mathrm{Rd}$, have been reported [11,16].

Recently, Ruan et al. [17] isolated the malonylginsenoside $\mathrm{Ra}_{3}$ from the root of $P$. ginseng. Zhu et al. [18] isolated 6 new protopanaxatriol-type ginsenosides, the ginsenosides $\mathrm{Re}_{1}, \mathrm{Re}_{2}, \mathrm{Re}_{3}, \mathrm{Re}_{4}, \mathrm{Re}_{5}, \mathrm{Re}_{6}$, and 10 known protopanaxatriol ginsenosides, including the ginsenoside $\mathrm{Rg}_{1}$ from the root of $P$. ginseng.

Approximately one thousand years ago, red (steamed) ginseng was developed to enhance the storage and the pharmacological effect of ginseng in Korea. Until recently, red ginseng had been widely made and largely consumed. Many scientists have isolated and identified its constituents to understand the pharmacological activities and bioactive components of red ginseng.

Table 1. Comparison of typical ginsenoside composition of Korean ginseng (Panax ginseng), American ginseng ( $P$. quinquefolius) and Notoginseng (P. notogisneng)

\begin{tabular}{lccc}
\hline Chemical composition & Korean ginseng & American ginseng & Notoginseng \\
\hline Major ginsenosides & $\mathrm{Rb}_{1}, \mathrm{Rg}_{1}, \mathrm{Rb}_{2}$ & $\mathrm{Rb}_{1}, \mathrm{Re}, \mathrm{Rd}$ & $\mathrm{Rb}_{1}, \mathrm{Rg}_{1}, \mathrm{Ra}_{3}, \mathrm{R}_{1}$ \\
PPD-group to PPT-group & $<2.0$ & $>2.0$ & $<2.0$ \\
$\mathrm{Rb}_{1}: \mathrm{Rg}_{1}$ & $<5.0$ & $>5.0$ & $<1$
\end{tabular}

PPD, protopanaxadiol; PPT, protopanaxatriol. 
Hiromichi et al. [19] isolated the ginsenosides $\mathrm{Ra}_{1}, \mathrm{Ra}_{2}$, and $\mathrm{Ra}_{3}$, and the notoginsenoside $\mathrm{R} 4$ from the steamed root of ginseng (red ginseng). Kasai et al. [20] isolated the ginsenosides $\mathrm{Ra}_{1}, \mathrm{Ra}_{2}, \mathrm{Ra}_{3}, \mathrm{Rs}_{1}$, and $\mathrm{Rs}_{2}$, the notoginsenoside R1, and the quinquenoside R1. Thereafter, the ginsenosides $R o, \mathrm{Rb}_{1}, \mathrm{Rb}_{2}, \mathrm{Tc}, \mathrm{Rd}, \mathrm{Re}, \mathrm{Rf}, \mathrm{Rg}_{1}, \mathrm{Rg}_{2}, \mathrm{Rg}_{3}$, $\mathrm{Rh}_{1}$, the ginsenosides $\mathrm{Rh}_{2}, 20 \mathrm{R}$-ginsenoside $\mathrm{Rh}_{1}, 20 \mathrm{~S}$ ginsenoside $\mathrm{Rg}_{3}$, and 20R-ginsenoside $\mathrm{Rg}_{2}$ were isolated from red ginseng. Ryu et al. [21] isolated the ginsenoside $\mathrm{Rg}_{6}$ and 20(E)-ginsenoside F4 from red ginseng. Baek et al. [22] isolated the ginsenoside $\mathrm{Rh}_{4}$. Then, the ginsenosides $\mathrm{Rs}_{1}, \mathrm{Rs}_{2}, \mathrm{Rs}_{3}$, and $\mathrm{Rs}_{4}$, the quinoginsenoside $\mathrm{R} 4$, the ginsenosides $\operatorname{Rg}_{3}, \mathrm{Rg}_{5}, \mathrm{Rg}_{6}, \mathrm{~F} 4$, and $\mathrm{Rf}_{2}$ were isolated from red ginseng $[23,24]$. In particular, large quantities of the ginsenosides $R h_{1}, R_{3}$ and $R g_{2}$ were found in red ginseng. Under intense steaming or heating, ginsenoside $\mathrm{Rg}_{3}$ may be further transformed to $20 \mathrm{~S}-\mathrm{Rh}_{2}$ and $20 \mathrm{R}-\mathrm{Rh}_{2}$, and these ginsenosides subsequently become aglycone 20S-protopanaxadiol, 20R-protopanaxadiol, or even 20-dehydroprotopanaxadiol through chemical degradation. Ginsenosides $\mathrm{Rk}_{1}$ and $\mathrm{Rg}_{5}$ are again transformed into the degradation products $\mathrm{Rk}_{2}$ and $\mathrm{Rh}_{3} . \mathrm{Rh}_{1}$ can be changed into the aglycones 20S-protopanaxatriol, 20Rprotopanaxatriol, and 20-dehydropropanaxatriol.

Shoji et al. [25] and Shoji et al. [26] were interested in the constituents of the leaves of $P$. ginseng. They isolated the ginsenosides $\mathrm{Rb}_{1}, \mathrm{Rb}_{2}, \mathrm{Rc}, \mathrm{Rd}, \mathrm{Re}, \mathrm{Rg}_{1}, \mathrm{~F} 1, \mathrm{~F} 2$, and F4 from the leaves and stems. The ginsenosides F4, 20Rprotopanaxadiol, 20R-protopanaxatriol, ginsenoside $\mathrm{Rh}_{3}$, 20R-ginsenoside $\mathrm{Rh}_{2}, 20 \mathrm{~S}$-ginsenoside $\mathrm{Rh}_{2}$, ginsenosides $\mathrm{Rh}_{1}, \mathrm{Rg}_{3}, \mathrm{Rg}_{2}, \mathrm{Rg}$, $\mathrm{Re}, \mathrm{Rd}, \mathrm{Rc}, \mathrm{Rb}_{2}$, and $\mathrm{Rb}_{1}$ were isolated from the flower buds of $P$. ginseng [27]. Ginsenosides $\mathrm{Rh}_{5}, \mathrm{Rh}_{6}, \mathrm{Rh}_{7}, \mathrm{Rh}_{8}, \mathrm{Rh}_{9}$ and $\mathrm{Rg}_{7}$, the majoroside $\mathrm{F} 1, \mathrm{~F} 2$, the notoginsenoside $\mathrm{Fe}$, the majoroside $\mathrm{F} 4$, and chikusetsusaponin L8 were also isolated $[28,29]$.

Recently, Tung et al. [30] isolated two new ginsenosides $\mathrm{Ki}$ and $\mathrm{Km}$ from the leaves of $P$. ginseng. Liu et al. [31] isolated three new ginsenosides, $20 \mathrm{~S}-3 \beta, 6 \alpha, 12 b$-,20-tetrahydroxydammara-25-ene-24one $20-O$ - $\beta$-glucopyranoside, $20 \mathrm{~S}-3 \beta, 6 \alpha, 12 \beta-, 20,24,25-$ pentahydroxydammarane $20-O-\beta$-D-glucopyranoside, $20 \mathrm{~S}, 23 \mathrm{E}-3 \beta, 6 \alpha, 12 \mathrm{~b}, 20,25$-tetrahydroxydammara-23ene $20-O-\beta$-glucopyranoside and six known compounds from the leaves of $P$. ginseng. Wu et al. [32] isolated $3 \beta, 6 \alpha, 12 \beta$-triol-22,23,23,25,26,27-hexanordammaran20 -one and dammar-20(22),24-diene-3 $\beta, 6 \alpha, 12 \beta$-triol from the leaves of $P$. ginseng. Huang et al. [33] isolated new 20R,22(xi),24(S)-dammar-25(26)-ene$3 \beta, 6 \alpha, 12 \beta, 20,22,24$-hexanol from the leaves of $P$. ginseng [34]. Tung et al. steamed the leaves of $P$. ginseng, and then investigated their constituents. They isolated new ginsenosides: SL-1, SL-2, SL3, and 11 known compounds [35].

Shoji et al. [26] also investigated the constituents of the flower buds of $P$. ginseng. They isolated ginsenosides

$\mathrm{Rb}_{1}, \mathrm{Rb}_{2}, \mathrm{Rc}, \mathrm{Rd}, \mathrm{Re}, \mathrm{Rg}_{1}, \mathrm{~F} 3$, and M7cd from the flower buds of $P$. ginseng. They also isolated ginsenosides $\mathrm{Rb}_{2}$, Rd, Rd, Re, $\mathrm{Rg}_{2}$, 20R-protopanaxatriol, 20Rginsenoside $\mathrm{Rh}_{1}$, 20R-ginsenoside $\mathrm{Rg}_{2}$, notoginsenosideE, and gypenoside XVII from the flower buds of $P$. ginseng [25]. Yoshikawa et al. [36] isolated new floralginsenosides A, B, C, D, E, and F from the flower buds of $P$. ginseng. They also isolated new floralginsenosides$\mathrm{M}, \mathrm{N}, \mathrm{O}$, and $\mathrm{P}$ and the ginsenosides Rd and Re [37]. Nguyen et al. [38] isolated new floralginsenosides-Ta, $\mathrm{Tb}$, Tc, and 6 known dammarane-type saponins from the flower buds of $P$. ginseng. Tung et al. [39] isolated antioxidant floralginsenosides $\mathrm{Ka}, \mathrm{Kb}$, and $\mathrm{Kc}$ from the flower buds of $P$. ginseng. Floralginsenosides Ka-Kc and majoroside $\mathrm{F} 1$ were also isolated from the flower buds of $P$. ginseng [39]. Recently, many researchers have been interested in the fruits and seeds of $P$. ginseng. Zhao et al. [40] isolated three new ginsenosides, 20R-25 methoxyldammarane-3 $\beta, 6 \alpha, 12 \beta, 20$-triol, 20R-25-methoxyldammarane-3 $\beta, 6 \alpha, 12 b, 20$-tetrol, and 20R-20,25 dimethoxyldammarane-3 $\beta, 6 \alpha, 12 \mathrm{~b}, 20$-diol, and 2 known ginsenosides from the fruit of $P$. ginseng. Sugimoto et al. [41] isolated a new type of saponin, called panaxadione, from the seeds of $P$. ginseng.

\section{Polysaccharides}

Many kinds of polysaccharides have been isolated from Korean ginseng. For example, Konno et al. [42], Konno et al. [43], and Ohshima et al. [44] isolated the hypoglycemic glycans, panasans A - E, poanaxans F $\mathrm{H}$, panaxans I - L, panaxans $\mathrm{M}$ - P, and panaxans Q - U from the root of $P$. ginseng. Tomoda et al. [45] and Tomoda et al. [46] isolated the immunomodulating glycans ginsenan $\mathrm{PA}$ and ginsenan $\mathrm{PB}$ from the root of $P$. ginseng. These immunomodulationg glycans are composed of Larabinose, D-galactose, L-rhamnose, Dgalacturonic acid, and D-glucuronic acid. However, the intact structures of these glycans have not been identified. Immunomodulating glycans, such as acidic polysaccharide ginsenan S-IA and ginsenan S-II A (MW 5.6×10, $1.0 \times 10^{5}$ ), have been continually reported.

\section{Others}

Favonoids and polyacetylenes, such as kaempferol, trifolin and panasenoside, were also isolated from the roots 
of $P$. ginseng. Matsunaga et al. [47] isolated polyacetylenes, panaxynol, and panaxydol.

Iwabuchi et al. [48] isolated two sesquierpene alcohols, pansinsanol A and panasinsanol B. Sesquiterpene hydrocarbons, $\alpha$-panasinene, $\beta$-panasinsene, $\alpha$-neoclovene, and $\beta$-panasinsene were also isolated from the rootlet. Furthermore, two new sesquitene alcohols, ginsenol and senecrassidiol, were found [49,50]. In addition, ginsenoynes A, B, C, D, E, F, G, H, I, J, and K have been reported.

\section{CHEMICAL DIVERSITY OF PANAX QUINQUI- FOLIUM}

American ginseng (P. quinquifolium L., family Araliaceae), a plant native to North America, is now cultivated in many countries. P. quinquifolium also contains saponins, flavonoids, polyacetylenes, polysaccharides, amino acids, fatty acids, and peptides.

\section{Saponins}

Saponins, particularly ginsenosides, are constituents of American ginseng (P. quinquifolium). More than 60 ginsenosides, including dammarane-, ocotillol-, and oleanane-types, have been isolated from the roots, leaves, stems, flower buds and berries of $P$. quinquifolium. Chen et al. [51] isolated quiquenosides L10 and L16 from the leaves and stems of $P$. quinquifolium. Jiang et al. [52] isolated two new saponins, $3 \beta, 12 \beta, 20 \mathrm{~S}$ trihydroxydammar23 -ene-3-O- $\{[\beta-\mathrm{D}$-glucopyranosyl( $1->2)-\beta$-D-

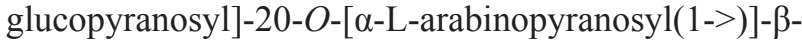
D-glucopyranoside and $3 \beta-20 \mathrm{~S}$-dihydroxy-12 $\beta$-23Repoxydammar-24-ene-3- $O$ - $\{[\beta$-D-glucopyranosyl(1$>2$ )- $\beta$-D-glucopyranosyl]-20- $O$-[ $\beta$-D-xylosyl(1->6)]- $\beta$ $\mathrm{D}$-glucopyranoside from the leaves of $P$. quinquifolium. Many ginsenosides have been isolated from $P$. quinquifolium. Protopanaxadiol-type ginsenosides isolated from the roots, leaves and stems, and flower buds of American ginseng are the ginsenosides $\mathrm{Rb}_{1}, \mathrm{Rc}, \mathrm{Rb}_{2}$, $\mathrm{Rb}_{3}, \mathrm{Rd}, \mathrm{Rg}_{3}, \mathrm{~F} 2, \mathrm{Rs}_{1}$, quinquenosides I, II, III, V, L10, L14, pseudoginsenosides RC1, F8, and gypenoside XVII [51-56]. Protopanaxatriol-type ginsenosides found in American ginseng are the ginsenosides $\mathrm{Rg}_{1}, \mathrm{Rg}_{2}, \mathrm{Re}$, $\mathrm{Rg}_{2}$, F3, Ia, F1, $\mathrm{Rh}_{1}$, 20S-acetyl ginsenoside $\mathrm{Rg}_{2}, 20 \mathrm{R}$ acetyl ginsenoside $\mathrm{Rg}_{2}$, floralquinquenoside $\mathrm{E}, 20 \mathrm{R}$ ginsenoside $\mathrm{Rg}_{2}, \mathrm{Rh}_{1}, 20 \mathrm{~S}$-protopanxatriol, and 20Rprotopanaxatriol $[52,54,56]$. Du et al. [57] isolated four malonyl-ginsenosides, $\mathrm{Rb}_{1}, \mathrm{Rc}, \mathrm{Rb}_{2}$, and $\mathrm{Rd}$. In addition, the minor ginsenosides 4 ocotillol-type ginsenosides (24Rpseudoginsenoside F11, pseudoginsenoside RT5,
F-11, 24R-vina-ginsenoside R1), 2 oleanane-type ginsenosides (ginsenoside Ro, chikusetsusaponin Iva), and 3 dammarane saponins with a modified steroid skeleton (vinaginsenoside $\mathrm{R} 3$, quinquenoside IV, and notoginsenoside G) were isolated from P. quinquifolium [54,56]. Minor saponins modified in C-20 side-chain (quinquenosides L1, L2, L8, L11, L3, L7, L9, L16, I, gypenosides LXIX, LXXI, majoroside-F1, notoginsenosides A, C, E, K, ginsenosides I, III, vina-ginsenoside R8, floralquinquenosides $\mathrm{B}, \mathrm{D}, \mathrm{A}, \mathrm{C}$, quinquefolosides $\mathrm{La}, \mathrm{Lc}$ ) were also isolated $[52,54,58]$. American red ginseng was also experimentally prepared under the same steam and heat treatments as Korean ginseng [59]. Then, the chemical composition of American red ginseng was studied. The constituents of the steamed American ginseng were largely different from those of the untreated ginseng. The steaming process induced obvious chemical degradation and conversion of original saponins to some newly occurring compounds. The polar ginsenosides, including $\mathrm{Rg}_{1}, \mathrm{Re}, \mathrm{Rb}_{1}, \mathrm{Rc}, \mathrm{Rb}_{2}, \mathrm{Rb}_{3}$, and $\mathrm{Rd}$, decreased remarkably; however, less polar ginsenosides, including $\mathrm{Rg}_{2}$, $\mathrm{Rg}_{3}, \mathrm{Rg}_{5}, \mathrm{Rh}_{2}, \mathrm{Rk}_{1}$, and $\mathrm{Rs}_{4}$, increased [60,61]. The 20S and 20R-ginsenoside are typical stereoisomers formed by the selective attack of the hydroxyl group after elimination of the glycosyl residue at C-20. Additionally, $\mathrm{Rk}_{1} /$ $\mathrm{Rg}_{5}$ and $\mathrm{Rk}_{3} / \mathrm{Rh}_{4}$, isomers of the double bond at C-20/21 or $\mathrm{C}-20 / 22$, were identified. This result was similar to the transformation of ginsenosides seen in Korean red ginseng.

Nakamura et al. [54] isolated five new dammaranetype triterpene glycosides, floralquinquenosides A, B, $\mathrm{C}, \mathrm{D}$, and $\mathrm{E}$, and 18 known dammarane-type triterpene glycosides, ginsenoside $\mathrm{Rb}_{3}$, ginsenoside $\mathrm{Rd}$, ginsenoside $\mathrm{Rs}_{1}$, pseudo-ginsenoside-RC1, pseudo-ginsenosideF8, quinquenoside III, ginsenoside I, notoginsenoside$\mathrm{E}$, ginsenoside $\mathrm{Re}$, ginsenoside $\mathrm{Rg}_{1}$, ginsenoside $\mathrm{Rg}_{2}$, ginsenoside-F3, ginsenoside Ia, quinquenoside L9, pseudo-ginsenoside RT5, pseudo-ginsenoside F11, and 24(S)-pseudo-ginsenoside F11 from the flower buds of $P$. quinquifolium L. Qiu et al. [62] isolated a new saponin quinquefoloside-L(c) $(3 \beta, 12 \beta, 20$ Strihydroxy25 -methoxy-25-methoxydammar-23-ene-3-O- $\beta$-Dglucopyranosyl(1->2) $\beta$-D-glucopyranosyl-20-O- $\beta$ xylopyranosyl(1->6)- $\beta$-D-glucopyranoside) from the leaves of $P$. quinquifolium. This saponin was found to be cytotoxic against tumor cells.

\section{Polysaccharides}

Many kinds of polysaccharides were also isolated from American ginseng. Immunomodulating glycans, such 
as water-soluble COLD-FX (CVT-E002), were isolated from the roots of $P$. quinquifolium [63]. These glycans are poly furanosyl-pyranosylsaccharides. Hypoglycemic glycans, such as quinquefolans $\mathrm{A}, \mathrm{B}$, and $\mathrm{C}$, were isolated from the roots of $P$. quinquifolium [64]. These glycans displayed hypoglycemic effects in normal and alloxaninduced hyperglycemic mice.

\section{Others}

Polyacetylenes, such as polyacetylene PQ-1, PQ2, PQ-3, panaxynol, panaxydol, and 1,8-heptadecadiene-4,6-diyne-3,10-diol, were isolated from the roots of P. quinquifolium [65-67]. Nakamura et al. [54] isolated three flavonoids and 3 flavonoid glycosides, kaempferol 3-O- $\beta$-D-sophoroside-7- $O-\alpha$-Lrhamnopyranoside, kaempferol- $O-(2,3-\mathrm{di}-\mathrm{E}-\mathrm{p}-\mathrm{cou}$ aroyl- $\alpha-\mathrm{L}$ rhamnopyranoside), and kaempferol-3-O- $\alpha$-L-rhamnopyranoside.

\section{CHEMICAL DIVERSITY OF PANAX NOTOGIN- SENG}

Notoginseng is also commonly used as a traditional Chinese medicine. Notoginseng contains saponins, flavonoids, polyacetylenes, polysaccharides, amino acids, fatty acids, and peptides. Ginsenosides and polysaccharides are notable components in $P$. notoginseng, just as they are in P. ginseng and P. quinquifolium $[68,69]$.

\section{Saponins}

More than 60 dammarane saponins have been isolated from the roots, rhizome, rootlets, fibers, leaves, flower

buds, seeds, and fruit pedicels of Notoginseng. Most of these saponins are ginsenosides and notoginsenosides.

However, an oleanolic acid saponin has not been found in Notoginseng. Oleanolic acid saponin occurs commonly in the plant kingdom and can be isolated from both Asian ginseng and American ginseng. The chemical constituents of American ginseng can be distinguished from those of Notoginseng. Yoshikawa et al. [70] and Yoshikawa et al. [71] isolated 9 dammaranetype triterpene glycosides, notoginsenosides-A, -B, -C, $-\mathrm{D},-\mathrm{E},-\mathrm{G},-\mathrm{H},-\mathrm{I}$, and $-\mathrm{J}$, and an acetylenic fatty acid glycoside, notoginsenic acid $\beta$-sophoroside. Chen and Sorensen [72] isolated ginsenosides $\mathrm{Rb}_{1}, \mathrm{Rb}_{2}, \mathrm{Rc}, \mathrm{Rd}$, $\mathrm{Re}, \mathrm{Rf}$, and Rg. Wei et al. [73], Wei et al. [74], and Wei et al. [75] subsequently reported the isolation of ginsenoside $\mathrm{Rb}_{1}$, notoginsenosides- $\mathrm{Fc}$ and $-\mathrm{Fa}$, and gypenosides XV and XVII. The genuine aglycones of these ginsenosides are hydrolyzed to panaxadiol and panaxatriol (dammar-20(22)-en-3 $\beta, 12 \beta, 26$-triol, and 20R-dammaran-3 $\beta, 12 \beta, 20,25$-tetrol) by acidic hydrolysis [76]. Cui et al. [76] isolated two new ginsenosides, notoginsenoside Rw1 [6-O- $\beta$-D-xylopranosyl-20-O- $\beta$ D-xylopyranosyl-(1->6)- $\beta$-D-glucopyranosyl-dammar$24-$ ene-3b,6a, 12b,20(S)tetraol] and Rw2 [6-O- $\beta$ Dxylopyranosyl-(1->2)- $\beta$-D-glucopyranosyl-dammar22 -ene-(trans)-3 $\beta, 6 \alpha, 12 \beta b, 20(\mathrm{~S}), 25$-pentaol], from the roots of $P$. notoginseng. Wan et al. [77] isolated 5,6-didehydroginsenoside $\mathrm{Rd}$, 5,6-didehydroginsenoside $\mathrm{Rb}_{1}$ from the root of $P$. notoginseng. Liu et al. [78] identified 151 saponins in the root of notoginseng by Esi-Ms, HPLC/ESI-MS(n). Of these, 56 new compounds were identified, although these compounds were not isolated.

Recently, Wang et al. [79] isolated 20S-25-methoxyldammarane-3 $\beta, 12 \beta, 20$-trio, a compound that exhibits potent cytotoxicity against tumor cells. Zhao et al. [80] isolated 20(S)-25-OCH3-protopanaxadiol, another cytotoxic compound against tumor cells, from the leaves of $P$. notoginseng. Wang et al. [81] isolated fl oranotoginsenosides-A, B, C, and D and 5 known compounds from the flower buds of $P$. notoginseng.

Sun et al. [82] steamed the root of notoginseng and isolated ginsenosides $\mathrm{Rg}_{1}, \mathrm{Re}, \mathrm{Rb}_{1}$, $\mathrm{Rd}$ and notoginsenoside R1 from Notoginseng. As seen on the steaming process of red ginseng, steaming notoginseng increased the contents of ginsenosides $\mathrm{Rh}_{1}, \mathrm{Rg}_{2}, \mathrm{Rg}_{3}, \mathrm{Rh}_{2}$, and 20Rginsenoside $\mathrm{Rg}_{2}$. Teng et al. [83] treated notoginseng roots under a specific mild acidic condition and isolated twenty saponins from them. Five isolated saponins were new dammarane glycosides, and these saponins were named as notoginsenosides T1-T5. Other saponins were the ginsenosides $\mathrm{Rg}_{5}, \mathrm{Rg}_{2}, \mathrm{Rg}_{1}, \mathrm{Re}, \mathrm{Rh}_{4}, \mathrm{Rd}, 20 \mathrm{R}$ ginsenoside $\mathrm{Rg}_{3}$, ginsenoside $\mathrm{Rg}_{3}$, 20R-ginsenoside $\mathrm{Rh}_{1}$, ginsenoside $\mathrm{Rh}_{1}$, the notoginsenosides $\mathrm{E}, \mathrm{R} 2$, and $\mathrm{R} 1$, the gypenoside XVII, 20R-25-hydroxyginsenoside $\mathrm{Rh}_{1}$, and 20S-25-hydroxyginsenoside $\mathrm{Rh}_{1}$.

\section{Polysaccharides}

Sanchinan-A $\left(1.5 \times 10^{6}\right)$, PF3111, PF3112, PBGA11, and PBGA12 were isolated from Notoginseng. These compounds showed immunostimulating activity [84].

\section{Others}

Choi et al. [85] isolated the $\beta$-amyloid-induced neurotoxicity-ameliorating constituent, quercetin-3- $\beta$ xylopyranosyl- $\beta-D$-galactopyranoside, from the root of Notoginseng. Wei et al. [73] isolated quercetin-3-Osophoroside, kaempferol-3-O(2"- $\beta$-D-glucopyranosyl)$\beta$-D-galactopyranoside, and quercetin-3-O(2" $-\beta$ - 
Dglucopyranosyl)- $\beta$-D-galactopyranoside from the leaves of $P$. notoginseng. Liu et al. [86] isolated polyacetylene compounds, and Chan et al. [87] isolated trilinolein from the roots of $P$. notoginseng.

\section{METABOLITES OF MAIN CONSTITUENTS AND THEIR BIOLOGICAL ACTIVITIES}

When ginseng is orally administered to humans, its main constituents (ginseng saponins and polysaccharides) cannot be easily absorbed from the intestine due to their hydrophilicity. Therefore, these constituents inevitably come into contact with intestinal microflora in the alimentary tract and can be metabolized by intestinal microflora $[88,89]$. The metabolites are then easily absorbed from the gastrointestinal tract because most of the metabolites are nonpolar. These absorbed metabolites may express pharmacological actions. For example, when the extract of the root of $P$. ginseng was orally administered to humans, compound $\mathrm{K}$ and ginsenosides $\mathrm{Rh}_{1}$ and $\mathrm{F} 1$ were detected in the blood $[90,91]$. Ginsenosides $\mathrm{Rb}_{1}$ and $R b_{2}$ were not detected. When ginsenoside $R b_{1}$, a main constituent of $P$. ginseng, was orally administered to conventional rats, compound $\mathrm{K}$ was detected in the intestinal contents, blood, and urine [92,93]. Ginsenoside $\mathrm{Rb}_{1}$ was not detected. Furthermore, compound $\mathrm{K}$ was detected in the blood and intestinal contents when ginsenoside $\mathrm{Rb}_{1}$ was orally administered to gnotobiotic rats [94]. However, when ginsenoside $\mathrm{Rb}_{1}$ was orally administered to germ-free rats, compound $\mathrm{K}$ and ginsenoside $\mathrm{Rb} b_{1}$ were not detected in the blood and intestinal contents. When Notoginseng extract, whose main constituents are ginsenoside $\mathrm{Ra}_{3}, \mathrm{Rb}_{1}, \mathrm{Rd}, \mathrm{Re}$, and $\mathrm{Rg}_{1}$ and notoginsenoside $\mathrm{R} 1$, was orally administered to rats, the compounds that were mainly absorbed into the blood were ginsenoside $\mathrm{Ra}_{2}, \mathrm{Rb}_{1}$, and $\mathrm{Rd}$ and compound $\mathrm{K}$ [95]. These results are not consistent. Neverthelse, compound K, a metabolites of protopanaxadiol ginsenosides, always are absorbed into the blood. Furthermore, of parental ginsenosides and their metabolites, compound $\mathrm{K}$, ginsenoside $\mathrm{Rh}_{1}, \mathrm{Rh}_{2}$, and protopanaxatriol showed the most potent biological effects compared with those of parental compounds. For example, compound $\mathrm{K}$ and 20(S)-ginsenoside $\mathrm{Rh}_{2}$ exhibited the most potent cytotoxicity against tumor cells $[96,97]$. Ginsenoside $\mathrm{Rb}_{1}$ and $\mathrm{Rb}_{2}$ did not exhibit cytotoxicity against the tumor cell lines. However, most ginsenosides have anti-tumor activities in vivo $[98,99]$. Therefore, the metabolism of ginseng constituents by intestinal microflora is likely to play an important role in the pharmacological activity of ginseng. Protopanaxadiol ginsenosides are metabolized to compound $\mathrm{K}$ by human intestinal microflora, such as Bifidobacterium K-110, Bifidobacterium H-1, Provetellaoris, Fusobacterium K-60, Bacteroides JY-6, Eubacterium A-44, and Bifidobacterium K-506 [89]. Protopanaxatriol saponin ginsenosides $\mathrm{Re}$ and $\mathrm{Rg}_{1}$ were easily transformed to ginsenoside $\mathrm{Rh}_{1}$ or protopanaxatriol by human intestinal bacteria, such as Fusobacterium K-60, Bacteroides JY-6, Eubacterium A-44, and Bacteroides HJ-15 [100,101].

\section{Compound K}

Compound K exhibits chemopreventive [97], chemotherapeutic [102], anti-inflammatory [103], hepatoprotective [92], anti-pruritic [104], antiallergic [105], and hypoglycemic [106] effects in vitro and in vivo. Compound $\mathrm{K}$ also reduced stress in mice [107].

\section{Ginsenoside $\mathbf{R h}_{\mathbf{2}}$}

Ginsenoside $\mathrm{Rh}_{2}$ showed anti-tumor [99], anti-inflammatory [108], anti-pruritic [109], antiallergic [106], hepatoprotective [110], hypoglycemic, and hypolipidemic effects in mice [111,102]. Ginsenoside $\mathrm{Rh}_{2}$ effectively inhibited adipocyte differentiation via PPAR- $\gamma$ inhibition [112] and improved insulin sensitivity [113]. Ginsenoside $\mathrm{Rh}_{2}$ ameliorated transient focal ischemia in rats [114].

\section{Ginsenoside $\mathbf{R h}_{\mathbf{1}}$}

Ginsenoside $\mathrm{Rh}_{1}$ exhibited anti-inflammatory [115], antiallergic [106], anti-dermatitic [116] effects in vitro and in vivo. Ginsenoside $\mathrm{Rh}_{1}$ showed anticarcinogenic and estrogenic effects [117] and stimulated the secretion of lipoprotein lipase in 3T3-L1 adipocytes [118].

\section{Protopanaxatriol}

Protopanaxatriol binds to glucocorticoid and estrogen receptors in endothelial cells and stimulates these receptors [119]. Protopanaxatriol (PPT) also has an estrogenic effect in MCF9 cells [120]. PPT has an adjuvant effect and activates PPAR $\gamma$ in 3T3-L1 adipocytes [121]. PPT also exhibits anti-inflammatory and antiangiogenic effects [122].

\section{ACIDIC POLYSACCHARIDES}

Ginseng polysaccharides are also degraded to low molecular weights by heat/steaming processing and intestinal microflora. However, the properties of the degraded molecules have not been clearly studied. Water-soluble polysaccharides and oligosaccharides from Korean ginseng have a number of effects on immune and host 
Table 2. Ginsenosides transformation by hydrolyzing the sugar moieties in ginsenosides using microbial glycosidases

\begin{tabular}{|c|c|c|c|c|}
\hline Substrate & Product & Microorganism & Enzyme & Reference \\
\hline Ginseng extract & $\mathrm{C}-\mathrm{K}$ & Bifidobacterium longum $H-1$ & $\beta$-D-Glucosidase/ $\alpha$-L-Arabinosidase & {$[131]$} \\
\hline Ginseng extract & & Sulfolobus solfataricus & $\beta$-D-Glycosidase (recombinant: 83 ) & [132] \\
\hline Ginseng extract & & Aspergillus niger & Pectinase (commercial) & [133] \\
\hline Ginseng extract & $\mathrm{Rh}_{2}$ & Bifidobacterium longum $\mathrm{H}-1$ & $\beta$-D-Glucosidase (crude) & [134] \\
\hline Ginseng extract & $\mathrm{Rg}_{3}$ & Trichoderma reesie & Cellulase (commercial) & {$[135]$} \\
\hline $\mathrm{Ra}_{1}, \mathrm{Ra}_{2}$ & $\mathrm{Rb}_{2}, \mathrm{Rc}$ & Bifidobacterium breve & $\beta$-D-Xylosidase (purified) & [136] \\
\hline Gypenoside-5 & $\mathrm{Rd}$ & Absidia sp. & $\alpha$-L-Rhamnosidase (purified) & [137] \\
\hline $\mathrm{Rb}_{2}$ & & Bifidobacterium breve & $\alpha$-L-Arabinopyranosidase (purified) & {$[138]$} \\
\hline $\mathrm{Rc}$ & & Bifidobacterium breve & $\alpha-\mathrm{L}$-Arabinopyranosidase (purified) & {$[136]$} \\
\hline $\mathrm{Rb}_{1}$ & & Chloroflexus aurantiacus & $\beta$-D-Glucosidase (recombinant) & [139] \\
\hline $\mathrm{Rb}_{1}$ & & Cladosprorium fulvum & $\beta$-D-Glucosidase (purified) & {$[140]$} \\
\hline $\mathrm{Rb}_{1}, \mathrm{Rb}_{2}, \mathrm{Rc}$ & & Thermus caldophilus & $\beta$-D-Glycosidase (recombinant) & [141] \\
\hline PPD mixture & & Trichoderma viride & Cellulase (commercial) & {$[142]$} \\
\hline $\mathrm{Rb}_{1}, \mathrm{Rb}_{2}, \mathrm{Rc}$ & $\mathrm{Rg}_{3}$ & Penicillium sp. & Lactase (commercial) & [143] \\
\hline $\mathrm{Rb}_{1}, \mathrm{Rd}$ & & Paecilomyces bainier & $\beta$-D-Glucosidase (purified) & [144] \\
\hline $\mathrm{Rb}_{1}, \mathrm{Rb}_{2}, \mathrm{Rc}$ & $\mathrm{F}_{2}$ & Aspergillus oryzae & Lactase (commercial) & [142] \\
\hline $\mathrm{Rb}_{1}, \mathrm{Rb}_{2}, \mathrm{Rc}$ & & Penicillium sp. & Lactase (commercial) & [143] \\
\hline $\mathrm{Rb}_{1}, \mathrm{Rb}, \mathrm{Rc}$ & $\mathrm{C}-\mathrm{K}, \mathrm{C}-\mathrm{Y}, \mathrm{C}-\mathrm{Mc}$ & Sulfolobus acidocaldarius & $\beta$-D-Glycosidase (recombinant) & {$[132]$} \\
\hline $\mathrm{Rb}_{1}, \mathrm{Rb}, \mathrm{Rc}$ & & Paecilomyces bainier & $\beta$-D-Glucosidase (purified) & {$[145]$} \\
\hline $\mathrm{Rb}_{1}$ & $\mathrm{C}-\mathrm{K}$ & Fusobacterium sp. & $\beta$-D-Glucosidase (purified) & [146] \\
\hline $\mathrm{Rb}_{1}, \mathrm{Rb}_{2}, \mathrm{Rc}$ & & Aspergillus oryzae & $\beta$-D-Galactosidase (commercial) & {$[142]$} \\
\hline $\mathrm{Rb}_{1}, \mathrm{Rb}_{2}, \mathrm{Rc}$ & & Penicillium sp. & Lactase (commercial) & [143] \\
\hline $\mathrm{Rb}_{1}, \mathrm{Rb}_{2}, \mathrm{Rb}_{3}, \mathrm{Rc}$ & & Aspergillus sp. & $\beta$-D-Glycosidase (purified) & [147] \\
\hline $\operatorname{Rg}_{3}$ & $\mathrm{Rh}_{2}$ & Fusarium proliferatum & $\beta$-D-Glucosidase (purified) & {$[148]$} \\
\hline $\operatorname{Re}$ & $\operatorname{Rg}_{1}$ & Penicillium sp. & Hesperidinase (commercial) & [143] \\
\hline $\operatorname{Re}$ & & Bacterodies sp. & $\alpha$-D-Rhamnosidase (purified) & [149] \\
\hline $\operatorname{Re}$ & $\mathrm{Rg}_{2}$ & Aspergillus oryzae & $\beta$-Galactosidase (commercial) & {$[142]$} \\
\hline $\operatorname{Re}$ & & Bacterodies sp. & $\beta$-D-Glucosidase (purified) & {$[150]$} \\
\hline $\operatorname{Rg}_{1}$ & $\mathrm{~F}_{1}$ & Bacterodies sp. & $\beta$-D-Glucosidase (purified) & {$[150]$} \\
\hline $\operatorname{Re}, \operatorname{Rg}_{1}$ & & Penicillium decumbens & Naringinase (commercial) & {$[142]$} \\
\hline $\operatorname{Rg}_{1}$ & $\mathrm{Rh}_{1}$ & Bacterodies sp. & $\beta$-D-Glucosidase (purified) & {$[150]$} \\
\hline $\operatorname{Rg}_{2}$ & & Aspergillus oryzae & $\beta$-Galactosidase (commercial) & [143] \\
\hline $\operatorname{Rg}_{2}$ & & Absidia sp. & $\alpha-\mathrm{L}-$ Rhamnosidase (purified) & {$[151]$} \\
\hline $\mathrm{Rg}_{1}, \mathrm{Rg}_{2}, \mathrm{Rf}$ & & Penicillium sp. & Lactase (commercial) & [143] \\
\hline $\mathrm{Rf}$ & & Aspergillus niger & $\beta$-D-Glucosidase (recombinant) & [152] \\
\hline
\end{tabular}

C-K, compound K; PPD, protopanaxadiol; C-Mc, compound Mc; C-Y, compound Y.

defense functions [123]. These glycans activate macrophages, induce IFN- $\gamma$ and TNF- $\alpha$ production in immune cells, stimulate phagocytosis [124], stimulate natural killer-cell activity [125], and activate components of cellmediated immunity [126]. Red ginseng acidic polysaccharides restored the proliferation of splenocytes and NK cell activity that had been suppressed by paclitaxel. Additionally, the synergistic effect of RGAP and paclitaxel increased the tumoricidal activity of macrophages [127]. Antirotaviral pectic polysaccharide was isolated from heat-processed ginseng [128]. 


\section{Industrial application}

When ginseng is orally administered to humans, its hydrophilic components inevitably come into contact with intestinal microflora in the alimentary tract and undergo transformation prior to absorption from the gastrointestinal tract. The pharmacological activities of these compounds are then expressed.

All individuals possess characteristic indigenous strains of intestinal bacteria. The activities that metabolize these constituents into bioactive compounds that are absorbable from the intestine into the blood differ significantly between individuals. Ginsengs containing bioactive and absorbable metabolites are valuable for treating various diseases. Therefore, fermented and heat-processed ginseng products have recently been released onto the market. Fermentation and heat processing transform hydrophilic components to hydrophobic compounds that can be easily absorbed from the gastrointestinal tract. To develop fermented ginseng, edible microbes, such as probiotics, should be used. Currently, there are few developed fermented ginsengs.

Therefore, research related to the biotransformation of ginsenosides is focused on bioactive production.

These metabolites, such as ginsenoside compound $\mathrm{K}$, $\mathrm{Rh}_{1}, \mathrm{Rh}_{2}, \mathrm{Rk}_{1}, \mathrm{Rh}_{3}, \mathrm{Rh}_{4}$, and protopanaxadiol, are readily absorbed into the blood and express pharmacological effects. These ginsenosides have demonstrated excellent potential for pharmacological use. To develop these ginsenosides, many kinds of microbes isolated from soils or intestinal microflora have been used (Table 2) $[129,130]$.

However, most of these biotransformed ginseng extracts are inedible, and most of these microbes may not be safe. Therefore, to develop fermented ginseng extract, we must consider fermented bacteria (Are these bacteria edible?) and safe metabolites (Are these metabolites produced by industrial applied microbes similar to metabolites produced by human intestinal microflora?). Nevertheless, these metabolites are good candidates for new drugs.

\section{CONCLUSION}

Korean ginseng, American ginseng, and Notoginseng contain saponins, which are found to be dammaranetype, ocotillol-type and oleanane-type oligoglycosides, and polysaccharides. Of these constituents, dammarane ginsenosides can be metabolized into compound $\mathrm{K}$, ginsenoside $\mathrm{Rh}_{1}$, and protopanaxatriol by intestinal microflora. These metabolites, such as compound $\mathrm{K}$ and protopanaxatriol, are pharmacologically active and easily absorbed from the gastrointestinal tract. However, the activities that metabolize these constituents into bioactive compounds differ significantly among individuals. To overcome this challenge, ginsengs have been fermented with enzymes or microbes to produce such metabolites. However, before using these enzymes and probiotics, the safety of these microbes and metabolites must be assessed. The safe ginseng bioproducts produced by enzymes or microbes are valuable for the development of new drugs and/or functional foods.

\section{REFERENCES}

1. Li CP, Li RC. An introductory note to ginseng. Am J Chin Med (Gard City N Y) 1973;1:249-261.

2. Attele AS, Wu JA, Yuan CS. Ginseng pharmacology: multiple constituents and multiple actions. Biochem Pharmacol 1999;58:1685-1693.

3. Kennedy DO, Scholey AB. Ginseng: potential for the enhancement of cognitive performance and mood. Pharmacol Biochem Behav 2003;75:687-700.

4. Singh VK, Agarwal SS, Gupta BM. Immunomodulatory activity of Panax ginseng extract. Planta Med 1984;50:462-465.

5. Scaglione F, Ferrara F, Dugnani S, Falchi M, Santoro G, Fraschini F. Immunomodulatory effects of two extracts of Panax ginseng C.A. Meyer. Drugs Exp Clin Res 1990;16:537-542.

6. Garriques SS. On panaquilon, a new vegetable substance. Ann Chem Pharm 1854;90:231-234.

7. Shibata S, Tanaka O, NagaI M, Ishit T. Studies on the constituents of Japanese and Chinese crude drugs. XII. Panaxadiol, a sapogenin of ginseng roots. Chem Pharm Bull (Tokyo) 1963;11:762-765.

8. Shibata S, Ando T, Tanaka O, Meguro Y, Sôma K, Iida Y. Saponins and sapogenins of Panax ginseng C.A. Meyer and some other Panax spp. Yakugaku Zasshi 1965;85:753-755.

9. Shibata S, Tanaka O, Soma K, AandoT, Iida Y, Nakamura H. Studies on saponins and sapogenins of ginseng. The structure of panaxatriol. Tetrahedron Lett 1965;42:207213.

10. Lu JM, Yao Q, Chen C. Ginseng compounds: an update on their molecular mechanisms and medical applications. Curr Vasc Pharmacol 2009;7:293-302.

11. Choi KT. Botanical characteristics, pharmacological effects and medicinal components of Korean Panax ginseng C A Meyer. Acta Pharmacol Sin 2008;29:1109-1118.

12. Yuan CS, Wang CZ, Wicks SM, Qi LW. Chemical and pharmacological studies of saponins with a focus on 
American ginseng. J Ginseng Res 2010;34:160-167.

13. Shibata S, Fujita M, Itokawa H, Tanaka O, Ishii T. Studies on the constituents of Japanese and Chinese crude drugs. XI. Panaxadiol, a sapogenin of ginseng roots. Chem Pharm Bull (Tokyo) 1963;11:759-761.

14. Kitagawa I, Taniyama T, Shibuya H, Noda T, Yoshikawa M. Chemical studies on crude drug processing. V. On the constituents of ginseng radix rubra (2): comparison of the constituents of white ginseng and red ginseng prepared from the same Panax ginseng root. Yakugaku Zasshi 1987; 107:495-505.

15. Kitagawa I, Yoshikawa M, Yoshihara M, Hayashi T, Taniyama T. Chemical studies of crude drugs (1). Constituents of ginseng radix rubra. Yakugaku Zasshi 1983;103:612622.

16. Haruyo K, Shuichi S, Yoshiteru I, Junzo S. Studies on the saponins of ginseng. IV. On the structure and enzymatic hydrolysis of ginsenoside $\mathrm{Ra}_{1}$. Chem Pharm Bull 1982;30:2393-2398.

17. Ruan CC, Liu Z, Li X, Liu X, Wang LJ, Pan HY, Zheng YN, Sun GZ, Zhang YS, Zhang LX. Isolation and characterization of a new ginsenoside from the fresh root of Panax ginseng. Molecules 2010;15:2319-2325.

18. Zhu GY, Li YW, Hau DK, Jiang ZH, Yu ZL, Fong WF. Protopanaxatriol-type ginsenosides from the root of Panax ginseng. J Agric Food Chem 2011;59:200-205.

19. Hiromichi B, Ryoji K, Yuhichiro S, Tohru F. Ginsenoside $\mathrm{Ra}_{1}$ and ginsenoside $\mathrm{Ra}_{2}$, new dammarane-saponins of ginseng roots. Chem Pharm Bull 1982;30:2380-2385.

20. Kasai R, Besso H, Tanaka O, Saruwatani Y, Fuwa T. Saponins of red ginseng. Chem Pharm Bull 1983;31:21202125.

21. Ryu JH, Park JH, Kim TH, Sohn DH, Kim JM, Park JH. A genuine dammarane glycoside, (20E)-ginsenoside F4 from Korean red ginseng. Arch Pharm Res 1996;19:335336.

22. Baek NI, Kim DS, Lee YH, Park JD, Lee CB, Kim SI. Ginsenoside $\mathrm{Rh}_{4}$, a genuine dammarane glycoside from Korean red ginseng. Planta Med 1996;62:86-87.

23. Baek NI, Kim JM, Park JH, Ryu JH, Kim DS, Lee YH, Park JD, Kim SI. Ginsenoside Rs(3), a genuine dammarane-glycoside from Korean red ginseng. Arch Pharm Res 1997;20:280-282.

24. Park JD, Lee YH, Kim SI. Ginsenoside $\mathrm{Rf}_{2}$, a new dammarane glycoside from Korean red ginseng (Panax ginseng). Arch Pharm Res 1998;21:615-617.

25. Shoji Y, Kiyoko K, Osamu T. Further study on dammarane-type saponins of roots, leaves, flower-buds, and fruits of Panax ginseng C.A. Meyer. Chem Pharm Bull 1979;27:88-92.
26. Shoji Y, Kiyoko M, Ryoji K, Osamu T. Saponins of buds and flowers of Panax ginseng C. A. Meyer. (1). Isolation of ginsenosides-Rd, -Re, and $-\mathrm{Rg}_{1}$. Chem Pharm Bull 1976;24:3212-3213.

27. Zhang S, Takeda T, Zhu T, Chen Y, Yao X, Tanaka O, Ogihara Y. A new minor saponin from the leaves of Panax ginseng. Planta Med 1990;56:298-300.

28. Dou DQ, Chen YJ, Liang LH, Pang FG, Shimizu N, Takeda T. Six new dammarane-type triterpene saponins from the leaves of Panax ginseng. Chem Pharm Bull (Tokyo) 2001;49:442-446.

29. Qiu F, Ma ZZ, Xu S, Yao XS, Chen YJ, Che ZT. Studies on dammarane-type saponins in the flower-buds of Panax ginseng C.A. Meyer. J Asian Nat Prod Res 1998;1:119123.

30. Tung NH, Song GY, Park YJ, Kim YH. Two new dammarane-type saponins from the leaves of Panax ginseng. Chem Pharm Bull 2009;57:1412-1414.

31. Liu GY, Li XW, Wang NB, Zhou HY, Wei W, Gui MY, Yang B, Jin YR. Three new dammarane-type triterpene saponins from the leaves of Panax ginseng C.A. Meyer. J Asian Nat Prod Res 2010;12:865-873.

32. Wu LJ, Wang LB, Gao HY, Wu B, Song XM, Tang ZS. A new compound from the leaves of Panax ginseng. Fitoterapia 2007;78:556-560.

33. Huang J, Tang XH, Ikejima T, Sun XJ, Wang XB, Xi $\mathrm{RG}, \mathrm{Wu} \mathrm{LJ}$. A new triterpenoid from Panax ginseng exhibits cytotoxicity through p53 and the caspase signaling pathway in the HepG2 cell line. Arch Pharm Res 2008;31:323-329.

34. Tung NH, Song GY, Minh CV, Kiem PV, Jin LG, Boo HJ, Kang HK, Kim YH. Steamed ginseng-leaf components enhance cytotoxic effects on human leukemia HL-60 cells. Chem Pharm Bull (Tokyo) 2010;58:1111-1115.

35. Tung NH, Quang TH, Son JH, Koo JE, Hong HJ, Koh YS, Song GY, Kim YH. Inhibitory effect of ginsenosides from steamed ginseng-leaves and flowers on the LPSstimulated IL-12 production in bone marrow-derived dendritic cells. Arch Pharm Res 2011;34:681-685.

36. Yoshikawa M, Sugimoto S, Nakamura S, Sakumae H, Matsuda H. Medicinal flowers. XVI. New dammaranetype triterpene tetraglycosides and gastroprotective principles from flower buds of Panax ginseng. Chem Pharm Bull (Tokyo) 2007;55:1034-1038.

37. Yoshikawa M, Sugimoto S, Nakamura S, Matsuda H. Medicinal flowers. XI. Structures of new dammarane-type triterpene diglycosides with hydroperoxide group from flower buds of Panax ginseng. Chem Pharm Bull (Tokyo) 2007;55:571-576.

38. Nguyen HT, Song GY, Kim JA, Hyun JH, Kang HK, Kim 
YH. Dammarane-type saponins from the flower buds of Panax ginseng and their effects on human leukemia cells. Bioorg Med Chem Lett 2010;20:309-314.

39. Tung NH, Song GY, Nhiem NX, Ding Y, Tai BH, Jin LG, Lim CM, Hyun JW, Park CJ, Kang HK et al. Dammarane-type saponins from the flower buds of Panax ginseng and their intracellular radical scavenging capacity. J Agric Food Chem 2010;58:868-874.

40. Zhao JM, Li N, Zhang H, Wu CF, Piao HR, Zhao YQ. Novel dammarane-type sapogenins from Panax ginseng berry and their biological activities. Bioorg Med Chem Lett 2011;21:1027-1031.

41. Sugimoto S, Nakamura S, Matsuda H, Kitagawa N, Yoshikawa M. Chemical constituents from seeds of Panax ginseng: structure of new dammarane-type triterpene ketone, panaxadione, and hplc comparisons of seeds and flesh. Chem Pharm Bull (Tokyo) 2009;57:283-287.

42. Konno C, Sugiyama K, Kano M, Takahashi M, Hikino H. Isolation and hypoglycaemic activity of panaxans A, B, C, D and E, glycans of Panax ginseng roots. Planta Med 1984;50:434-436.

43. Konno C, Murakami M, Oshima Y, Hikino H. Isolation and hypoglycemic activity of panaxans Q, R, S, T and $\mathrm{U}$, glycans of Panax ginseng roots. J Ethnopharmacol 1985;14:69-74.

44. Oshima Y, Konno C, Hikino H. Isolation and hypoglycemic activity of panaxans I, J, K and L, glycans of Panax ginseng roots. J Ethnopharmacol 1985;14:255-259.

45. Tomoda M, Takeda K, Shimizu N, Gonda R, Ohara N, Takada K, Hirabayashi K. Characterization of two acidic polysaccharides having immunological activities from the root of Panax ginseng. Biol Pharm Bull 1993;16:22-25.

46. Tomoda M, Hirabayashi K, Shimizu N, Gonda R, Ohara N, Takada K. Characterization of two novel polysaccharides having immunological activities from the root of Panax ginseng. Biol Pharm Bull 1993;16:1087-1090.

47. Matsunaga H, Katano M, Yamamoto H, Mori M, Takata K. Studies on the panaxytriol of Panax ginseng C. A. Meyer. Isolation, determination and antitumor activity. Chem Pharm Bull (Tokyo) 1989;37:1279-1281.

48. Iwabuchi H, Yoshikura M, Ikawa Y, Kamisako W. Studies on the sesquiterpenoids of Panax ginseng C. A. Meyer. Isolation and structure determination of sesquiterpene alcohols, panasinsanols A and B. Chem Pharm Bull (Tokyo) 1987;35:1975-1981.

49. Iwabuchi H, Yoshikura M, Kamisako W. Studies on the sesquiterpenoids of Panax ginseng C. A. Meyer. II. Isolation and structure determination of ginsenol, a novel sesquiterpene alcohol. Chem Pharm Bull (Tokyo) 1988;36:2447-2451.
50. Iwabuchi H, Kato N, Yoshikura M. Studies on the sesquiterpenoids of Panax ginseng C. A. Meyer. IV. Chem Pharm Bull (Tokyo) 1990;38:1405-1407.

51. Chen J, Zhao R, Zeng YM, Meng H, Zuo WJ, Li X, Wang JH. Three new triterpenoid saponins from the leaves and stems of Panax quinquefolium. J Asian Nat Prod Res 2009;11:195-201.

52. Jiang HP, Qiu YK, Cheng DR, Kang TG, Dou DQ. Structure elucidation and complete NMR spectral assignments of two new dammarane-type tetraglycosides from Panax quinquefolium. Magn Reson Chem 2008;46:786-790.

53. Li GY, Zeng YM, Meng H, Li X, Wang JH. A new triterpenoid saponin from the leaves and stems of Panax quinquefolium L. Chin Chem Lett 2009;20:1207-1210.

54. Nakamura S, Sugimoto S, Matsuda H, Yoshikawa M. Medicinal flowers. XVII. New dammarane-type triterpene glycosides from flower buds of American ginseng, Panax quinquefolium L. Chem Pharm Bull (Tokyo) 2007;55:1342-1348.

55. Wang JH, Li W, Sha Y, Tezuka Y, Kadota S, Li X. Triterpenoid saponins from leaves and stems of Panax quinquefolium L. J Asian Nat Prod Res 2001;3:123-130.

56. Yoshikawa M, Murakami T, Yashiro K, Yamahara J, Matsuda H, Saijoh R, Tanaka O. Bioactive saponins and glycosides. XI. Structures of new dammarane-type triterpene oligoglycosides, quinquenosides I, II, III, IV, and V, from American ginseng, the roots of Panax quinquefolium L. Chem Pharm Bull (Tokyo) 1998;46:647-654.

57. Du XW, Wills RB, Stuart DL. Changes in neutral and malonyl ginsenosides in American ginseng (Panax quinquefolium) during drying, storage and ethanolic extraction. Food Chem 2004;86:155-159.

58. Xie G, Plumb R, Su M, Xu Z, Zhao A, Qiu M, Long X, Liu Z, Jia W. Ultra-performance LC/TOF MS analysis of medicinal Panax herbs for metabolomic research. J Sep Sci 2008;31:1015-1026.

59. Ren G, Chen F. Degradation of ginsenosides in American ginseng (Panax quinquefolium) extracts during microwave and conventional heating. J Agric Food Chem 1999;47:1501-1505.

60. Wang CZ, Zhang B, Song WX, Wang A, Ni M, Luo X, Aung HH, Xie JT, Tong R, He TC et al. Steamed American ginseng berry: ginsenoside analyses and anticancer activities. J Agric Food Chem 2006;54:9936-9942.

61. Wang CZ, Aung HH, Ni M, Wu JA, Tong R, Wicks S, He TC, Yuan CS. Red American ginseng: ginsenoside constituents and antiproliferative activities of heat-processed Panax quinquefolius roots. Planta Med 2007;73:669-674.

62. Qiu YK, Dou DQ, Cai LP, Jiang HP, Kang TG, Yang BY, Kuang HX, Li MZ. Dammarane-type saponins from 
Panax quinquefolium and their inhibition activity on human breast cancer MCF-7 cells. Fitoterapia 2009;80:219222.

63. Wang M, Guilbert LJ, Li J, Wu Y, Pang P, Basu TK, Shan JJ. A proprietary extract from North American ginseng (Panax quinquefolium) enhances IL-2 and IFN-gamma productions in murine spleen cells induced by Con-A. Int Immunopharmacol 2004;4:311-315.

64. Oshima Y, Sato K, Hikino H. Isolation and hypoglycemic activity of quinquefolans A, B, and C, glycans of Panax quinquefolium roots. J Nat Prod 1987;50:188-190.

65. Christensen LP, Jensen M, Kidmose U. Simultaneous determination of ginsenosides and polyacetylenes in American ginseng root (Panax quinquefolium L.) by highperformance liquid chromatography. J Agric Food Chem 2006;54:8995-9003.

66. Baranska M, Schulz H, Christensen LP. Structural changes of polyacetylenes in American ginseng root can be observed in situ by using Raman spectroscopy. J Agric Food Chem 2006;54:3629-3635.

67. Washida D, Kitanaka S. Determination of polyacetylenes and ginsenosides in Panax species using high performance liquid chromatography. Chem Pharm Bull (Tokyo) 2003;51:1314-1317.

68. Wang CZ, McEntee E, Wicks S, Wu JA, Yaun CS. Phytochemical and analytical studies of Panax notoginseng (Burk.) F.H. Chen. J Nat Med 2006;60:97-106.

69. Zhu S, Zou K, Fushimi H, Cai S, Komatsu K. Comparative study on triterpene saponins of ginseng drugs. Planta Med 2004;70:666-677.

70. Yoshikawa M, Morikawa T, Yashiro K, Murakami T, Matsuda H. Bioactive saponins and glycosides. XIX. Notoginseng (3): immunological adjuvant activity of notoginsenosides and related saponins: structures of notoginsenosides- $\mathrm{L}$, $-\mathrm{M}$, and $-\mathrm{N}$ from the roots of Panax notoginseng (Burk.) F. H. Chen. Chem Pharm Bull (Tokyo) 2001;49:1452-1456.

71. Yoshikawa M, Murakami T, Ueno T, Yashiro K, Hirokawa N, Murakami N, Yamahara J, Matsuda H, Saijoh $\mathrm{R}$, Tanaka O. Bioactive saponins and glycosides. VIII. Notoginseng (1): new dammarane-type triterpene oligoglycosides, notoginsenosides-A, $-\mathrm{B},-\mathrm{C}$, and $-\mathrm{D}$, from the dried root of Panax notoginseng (Burk.) F.H. Chen. Chem Pharm Bull (Tokyo) 1997;45:1039-1045.

72. Chen Y, Sorensen LK. Determination of marker constituents in radix Glycyrrhizae and radix Notoginseng by near infrared spectroscopy. Fresenius J Anal Chem 2000;367:491-496.

73. Wei JX, Wang LA, Du H, Li R. Isolation and identification of sanchinoside B1 and B2 from rootlets of Panax notoginseng (Burk.) F. H. Chen. Yao Xue Xue Bao 1985;20:288-293.

74. Wei JX, Wang JF, Chang LY, Du YC. Chemical studies of san-chi Panax notoginseng (Burk.) F. H. Chen. I. Studies on the constituents of San-Chi root hairs. Yao Xue Xue Bao 1980;15:359-364.

75. Wei JX, Liangyu C, Jufen W, Friedrichs E, Jores M, Puff $\mathrm{H}$, Breitmaier E. Two new dammaran sapogenins from leaves of Panax notoginseng. Planta Med 1982;45:167171.

76. Cui XM, Jiang ZY, Zeng J, Zhou JM, Chen JJ, Zhang $\mathrm{XM}, \mathrm{Xu} \mathrm{LS}$, Wang Q. Two new dammarane triterpene glycosides from the rhizomes of Panax notoginseng. J Asian Nat Prod Res 2008;10:845-849.

77. Wan JB, Zhang QW, Hong SJ, Guan J, Ye WC, Li SP, Lee MY, Wang YT. 5,6-Didehydroginsenosides from the roots of Panax notoginseng. Molecules 2010;15:8169-8176.

78. Liu Y, Li J, He J, Abliz Z, Qu J, Yu S, Ma S, Liu J, Du D. Identification of new trace triterpenoid saponins from the roots of Panax notoginseng by high-performance liquid chromatography coupled with electrospray ionization tandem mass spectrometry. Rapid Commun Mass Spectrom 2009;23:667-679.

79. Wang W, Rayburn ER, Hang J, Zhao Y, Wang H, Zhang R. Anti-lung cancer effects of novel ginsenoside 25-OCH(3)PPD. Lung Cancer 2009;65:306-311.

80. Zhao Y, Wang W, Han L, Rayburn ER, Hill DL, Wang H, Zhang R. Isolation, structural determination, and evaluation of the biological activity of 20(S)-25-methoxyldammarane-3beta, 12beta, 20-triol [20(S)-25-OCH3PPD], a novel natural product from Panax notoginseng. Med Chem 2007;3:51-60.

81. Wang JR, Yamasaki Y, Tanaka T, Kouno I, Jiang ZH. Dammarane-type triterpene saponins from the flowers of Panax notoginseng. Molecules 2009;14:2087-2094.

82. Sun S, Wang CZ, Tone R, Li XL, Fishbein A, Wang Q, He TC, Du W, Yuan CS. Effects of steaming the root of Panax notoginseng on chemical composition and anticancer activities. Food Chem 2010;118:307-314.

83. Teng RW, Li HZ, Wang DZ, Yang CR. Hydrolytic reaction of plant extracts to generate molecular diversity: new dammarane glycosides from the mild acid hydrolysate of root saponins of Panax notoginseng. Helv Chim Acta 2004;87:1270-1278.

84. Ohtani K, Mizutani K, Hatono S, Kasai R, Sumino R, Shiota T, Ushijima M, Zhou J, Fuwa T, Tanaka O. Sanchinan-A, a reticuloendothelial system activating arabinogalactan from sanchi-ginseng (roots of Panax notoginseng). Planta Med 1987;53:166-169.

85. Choi RC, Zhu JT, Leung KW, Chu GK, Xie HQ, Chen 
VP, Zheng KY, Lau DT, Dong TT, Chow PC et al. A flavonol glycoside, isolated from roots of Panax notoginseng, reduces amyloid-beta-induced neurotoxicity in cultured neurons: signaling transduction and drug development for Alzheimer's disease. J Alzheimers Dis 2010;19:795-811.

86. Liu JH, Lee CS, Leung KM, Yan ZK, Shen BH, Zhao ZZ, Jiang ZH. Quantification of two polyacetylenes in Radix Ginseng and roots of related Panax species using a gas chromatography-mass spectrometric method. J Agric Food Chem 2007;55:8830-8835.

87. Chan P, Thomas GN, Tomlinson B. Protective effects of trilinolein extracted from Panax notoginseng against cardiovascular disease. Acta Pharmacol Sin 2002;23:11571162.

88. Kobashi K, Akao T. Relation of intestinal bacteria to pharmacological effects of glycosides. Bioscience Microflora 1997;16:1-7.

89. Kim DH. Herbal medicines are activated by intestinal microflora. Nat Prod Sci 2002;8:35-43.

90. Tawab MA, Bahr U, Karas M, Wurglics M, Schubert-Zsilavecz M. Degradation of ginsenosides in humans after oral administration. Drug Metab Dispos 2003;31:10651071.

91. Karikura M, Miyase T, Tanizawa H, Taniyama T, Takino Y. Studies on absorption, distribution, excretion and metabolism of ginseng saponins. VII. Comparison of the decomposition modes of ginsenoside- $R b_{1}$ and $-R b_{2}$ in the digestive tract of rats. Chem Pharm Bull (Tokyo) 1991;39:2357-2361.

92. Lee HU, Bae EA, Han MJ, Kim NJ, Kim DH. Hepatoprotective effect of ginsenoside $\mathrm{Rb}_{1}$ and compound $\mathrm{K}$ on tert-butyl hydroperoxide-induced liver injury. Liver Int 2005;25:1069-1073.

93. Akao T, Kida H, Kanaoka M, Hattori M, Kobashi K. Intestinal bacterial hydrolysis is required for the appearance of compound $\mathrm{K}$ in rat plasma after oral administration of ginsenoside Rb1 from Panax ginseng. J Pharm Pharmacol 1998;50:1155-1160.

94. Akao T, Kanaoka M, Kobashi K. Appearance of compound $\mathrm{K}$, a major metabolite of ginsenoside $\mathrm{Rb}_{1}$ by intestinal bacteria, in rat plasma after oral administration: measurement of compound $\mathrm{K}$ by enzyme immunoassay. Biol Pharm Bull 1998;21:245-249.

95. Liu H, Yang J, Du F, Gao X, Ma X, Huang Y, Xu F, Niu W, Wang F, Mao Y et al. Absorption and disposition of ginsenosides after oral administration of Panax notoginseng extract to rats. Drug Metab Dispos 2009;37:2290-2298.

96. Shibata S. Chemistry and cancer preventing activities of ginseng saponins and some related triterpenoid com- pounds. J Korean Med Sci 2001;16 Suppl:S28-S37.

97. Shin JE, Park EK, Kim EJ, Hong YH, Lee KT, Kim DH. Cytotoxicity of compound $\mathrm{K}$ (IH-901) and ginsenoside $\mathrm{Rh}_{2}$, main biotransformants of ginseng saponins by bifidobacteria, against some tumor cells. J Ginseng Res 2003;27:129-134.

98. Choo MK, Sakurai H, Kim DH, Saiki I. A ginseng saponin metabolite suppresses tumor necrosis factor-alphapromoted metastasis by suppressing nuclear factorkappaB signaling in murine colon cancer cells. Oncol Rep 2008;19:595-600.

99. Nakata H, Kikuchi Y, Tode T, Hirata J, Kita T, Ishii K, Kudoh K, Nagata I, Shinomiya N. Inhibitory effects of ginsenoside $\mathrm{Rh}_{2}$ on tumor growth in nude mice bearing human ovarian cancer cells. Jpn J Cancer Res 1998;89:733-740.

100. Bae EA, Park SY, Kim DH. Constitutive beta-glucosidases hydrolyzing ginsenoside $\mathrm{Rb}_{1}$ and $\mathrm{Rb}_{2}$ from human intestinal bacteria. Biol Pharm Bull 2000;23:1481-1485.

101. Bae EA, Han MJ, Kim EJ, Kim DH. Transformation of ginseng saponins to ginsenoside $\mathrm{Rh}_{2}$ by acids and human intestinal bacteria and biological activities of their transformants. Arch Pharm Res 2004;27:61-67.

102. Lee SJ, Sung JH, Lee SJ, Moon CK, Lee BH. Antitumor activity of a novel ginseng saponin metabolite in human pulmonary adenocarcinoma cells resistant to cisplatin. Cancer Lett 1999;144:39-43.

103. Park EK, Shin YW, Lee HU, Kim SS, Lee YC, Lee $\mathrm{BY}, \mathrm{Kim} \mathrm{DH}$. Inhibitory effect of ginsenoside $\mathrm{Rb}_{1}$ and compound $\mathrm{K}$ on $\mathrm{NO}$ and prostaglandin E2 biosyntheses of RAW264.7 cells induced by lipopolysaccharide. Biol Pharm Bull 2005;28:652-656.

104. Shin YW, Kim DH. Antipruritic effect of ginsenoside rb1 and compound $\mathrm{k}$ in scratching behavior mouse models. J Pharmacol Sci 2005;99:83-88.

105. Choo MK, Park EK, Han MJ, Kim DH. Antiallergic activity of ginseng and its ginsenosides. Planta Med 2003;69:518-522.

106. Han GC, Ko SK, Sung JH, Chung SH. Compound K enhances insulin secretion with beneficial metabolic effects in db/db mice. J Agric Food Chem 2007;55:10641-10648.

107. Kim DH, Jung JS, Moon YS, Sung JH, Suh HW, Kim $\mathrm{YH}$, Song DK. Inhibition of intracerebroventricular injection stress-induced plasma corticosterone levels by intracerebroventricularly administered compound $\mathrm{K}$, a ginseng saponin metabolite, in mice. Biol Pharm Bull 2003;26:1035-1038.

108. Bae EA, Kim EJ, Park JS, Kim HS, Ryu JH, Kim DH. Ginsenosides $\mathrm{Rg}_{3}$ and $\mathrm{Rh}_{2}$ inhibit the activation of AP-1 and protein kinase A pathway in lipopolysaccharide/in- 
terferon-gamma-stimulated BV-2 microglial cells. Planta Med 2006;72:627-633.

109. Park EK, Choo MK, Kim EJ, Han MJ, Kim DH. Antiallergic activity of ginsenoside $\mathrm{Rh}_{2}$. Biol Pharm Bull 2003;26:1581-1584.

110. Lee HU, Bae EA, Han MJ, Kim DH. Hepatoprotective effect of 20(S)-ginsenosides $\mathrm{Rg}_{3}$ and its metabolite 20(S)ginsenoside $\mathrm{Rh}_{2}$ on tert-butyl hydroperoxide-induced liver injury. Biol Pharm Bull 2005;28:1992-1994.

111. Trinh HT, Han SJ, Kim SW, Lee YC, Kim DH. Bifidus fermentation increases hypolipidemic and hypoglycemic effects of red ginseng. J Microbiol Biotechnol 2007; 17:1127-1133.

112. Hwang JT, Kim SH, Lee MS, Kim SH, Yang HJ, Kim MJ, Kim HS, Ha J, Kim MS, Kwon DY. Anti-obesity effects of ginsenoside $\mathrm{Rh}_{2}$ are associated with the activation of AMPK signaling pathway in 3T3-L1 adipocyte. Biochem Biophys Res Commun 2007;364:1002-1008.

113. Lee WK, Kao ST, Liu IM, Cheng JT. Increase of insulin secretion by ginsenoside $\mathrm{Rh}_{2}$ to lower plasma glucose in Wistar rats. Clin Exp Pharmacol Physiol 2006;33:27-32.

114. Park EK, Choo MK, Oh JK, Ryu JH, Kim DH. Ginsenoside $\mathrm{Rh}_{2}$ reduces ischemic brain injury in rats. Biol Pharm Bull 2004;27:433-436.

115. Jung JS, Shin JA, Park EM, Lee JE, Kang YS, Min SW, Kim DH, Hyun JW, Shin CY, Kim HS. Anti-inflammatory mechanism of ginsenoside $\mathrm{Rh}_{1}$ in lipopolysaccharidestimulated microglia: critical role of the protein kinase A pathway and hemeoxygenase-1 expression. J Neurochem 2010;115:1668-1680.

116. Park EK, Choo MK, Han MJ, Kim DH. Ginsenoside Rh possesses antiallergic and anti-inflammatory activities. Int Arch Allergy Immunol 2004;133:113-120.

117. Lee Y, Jin Y, Lim W, Ji S, Choi S, Jang S, Lee S. A ginsenoside- $\mathrm{Rh}_{1}$, a component of ginseng saponin, activates estrogen receptor in human breast carcinoma MCF7 cells. J Steroid Biochem Mol Biol 2003;84:463-468.

118. Masuno H, Kitao T, Okuda H. Ginsenosides increase secretion of lipoprotein lipase by 3T3-L1 adipocytes. Biosci Biotechnol Biochem 1996;60:1962-1965.

119. Leung KW, Leung FP, Mak NK, Tombran-Tink J, Huang Y, Wong RN. Protopanaxadiol and protopanaxatriol bind to glucocorticoid and oestrogen receptors in endothelial cells. Br J Pharmacol 2009;156:626-637.

120. Bae EA, Shin JE, Kim DH. Metabolism of ginsenoside Re by human intestinal microflora and its estrogenic effect. Biol Pharm Bull 2005;28:1903-1908.

121. Han KL, Jung MH, Sohn JH, Hwang JK. Ginsenoside 20S-protopanaxatriol (PPT) activates peroxisome proliferator-activated receptor gamma (PPARgamma) in 3T3-
L1 adipocytes. Biol Pharm Bull 2006;29:110-113.

122. Usami Y, Liu YN, Lin AS, Shibano M, Akiyama T, Itokawa H, Morris-Natschke SL, Bastow K, Kasai R, Lee KH. Antitumor agents. 261. 20(S)-protopanaxadiol and 20(s)-protopanaxatriol as antiangiogenic agents and total assignment of (1)H NMR spectra. J Nat Prod 2008;71:478-481.

123. Wang M, Guilbert LJ, Ling L, Li J, Wu Y, Xu S, Pang P, Shan JJ. Immunomodulating activity of CVT-E002, a proprietary extract from North American ginseng (Panax quinquefolium). J Pharm Pharmacol 2001;53:1515-1523.

124. Hu S, Concha C, Cooray R, Holmberg O. Ginsengenhanced oxidative and phagocytic activities of polymorphonuclear leucocytes from bovine peripheral blood and stripping milk. Vet Res 1995;26:155-161.

125. Kim JY, Germolec DR, Luster MI. Panax ginseng as a potential immunomodulator: studies in mice. Immunopharmacol Immunotoxicol 1990;12:257-276.

126. Hwang I, Ahn G, Park E, Ha D, Song JY, Jee Y. An acidic polysaccharide of Panax ginseng ameliorates experimental autoimmune encephalomyelitis and induces regulatory T cells. Immunol Lett 2011;138:169-178.

127. Shin HJ, Kim YS, Kwak YS, Song YB, Kim YS, Park JD. Enhancement of antitumor effects of paclitaxel (taxol) in combination with red ginseng acidic polysaccharide (RGAP). Planta Med 2004;70:1033-1038.

128. Baek SH, Lee JG, Park SY, Bae ON, Kim DH, Park JH. Pectic polysaccharides from Panax ginseng as the antirotavirus principals in ginseng. Biomacromolecules 2010;11:2044-2052.

129. Metabolism of ginsenosides to bioactive compounds by intestinal microflora and its industrial application. J Ginseng Res 2009;33:165-176.

130. Park CS, Yoo MH, Noh KH, Oh DK. Biotransformation of ginsenosides by hydrolyzing the sugar moieties of ginsenosides using microbial glycosidases. Appl Microbiol Biotechnol 2010;87:9-19.

131. Lee JH, Hyun YJ, Kim DH. Cloning and characterization of $\alpha$-L-arabinofuranosidase and bifunctional $\alpha$-L-arabinopyranosidase/ $\beta$-D-galactopyranosidase from Bifidobacterium longum H-1. J Appl Microbiol 2011;111:1097-1107.

132. Noh KH, Son JW, Kim HJ, Oh DK. Ginsenoside compound $\mathrm{K}$ production from ginseng root extract by a thermostable beta-glycosidase from Sulfolobus solfataricus. Biosci Biotechnol Biochem 2009;73:316-321.

133. Kim BH, Lee SY, Cho HJ, You SN, Kim YJ, Park YM, Lee JK, Baik MY, Park CS, Ahn SC. Biotransformation of Korean Panax ginseng by pectinex. Biol Pharm Bull 2006;29:2472-2478. 
134. Park EK, Choo MK, Oh JK, Ryu JH, Kim DH. Ginsenoside $\mathrm{Rh}_{2}$ reduces ischemic brain injury in rats. Biol Pharm Bull 2004;27:433-436.

135. Chang KH, Jee HS, Lee NK, Park SH, Lee NW, Paik HD. Optimization of the enzymatic production of 20(S)ginsenoside $\operatorname{Rg}(3)$ from white ginseng extract using response surface methodology. N Biotechnol 2009;26:181186.

136. Shin HY, Lee JH, Lee JY, Han YO, Han MJ, Kim DH. Purification and characterization of ginsenoside Ra-hydrolyzing beta-D-xylosidase from Bifidobacterium breve $\mathrm{K}-110$, a human intestinal anaerobic bacterium. Biol Pharm Bull 2003;26:1170-1173.

137. Yu H, Liu H, Zhang C, Tan D, Lu M, Jin F. Purification and characterization of gypenoside-alpha-L-rhamnosidase hydrolyzing gypenoside-5 into ginsenoside Rd. Process Biochem 2004;39:861-867.

138. Shin HY, Park SY, Sung JH, Kim DH. Purification and characterization of alpha-L-arabinopyranosidase and alpha-L-arabinofuranosidase from Bifidobacterium breve K-110, a human intestinal anaerobic bacterium metabolizing ginsenoside $\mathrm{Rb}_{2}$ and $\mathrm{Rc}$. Appl Environ Microbiol 2003;69:7116-7123.

139. Kim SJ, Lee CM, Kim MY, Yeo YS, Yoon SH, Kang $\mathrm{HC}$, Koo BS. Screening and characterization of an enzyme with beta-glucosidase activity from environmental DNA. J Microbiol Biotechnol 2007;17:905-912.

140. Zhao X, Gao L, Wang J, Bi H, Gao J, Du X, Zhou Y, Tai G. A novel ginsenoside $\mathrm{Rb}_{1}$-hydrolyzing beta-D-glucosidase from Cladosprium fulvum. Process Biochem 2009; 44:612-618.

141. Son JW, Kim HJ, Oh DK. Ginsenoside Rd production from the major ginsenoside $\mathrm{Rb}_{1}$ by beta-glucosidase from Thermus caldophilus. Biotechnol Lett 2008;30:713-716.

142. Ko SR, Suzuki Y, Suzuki K, Choi KJ, Cho BG. Marked production of ginsenosides $\mathrm{Rd}, \mathrm{F} 2, \mathrm{Rg}_{3}$, and compound $\mathrm{K}$ by enzymatic method. Chem Pharm Bull (Tokyo) 2007;55:1522-1527.

143. Ko SR, Choi KJ, Suzuki K, Suzuki Y. Enzymatic prepa- ration of ginsenosides $\mathrm{Rg}_{2}, \mathrm{Rh}_{1}$, and $\mathrm{F} 1$. Chem Pharm Bull (Tokyo) 2003;51:404-408.

144. Yan Q, Zhou W, Li X, Feng M, Zhou P. Purification method improvement and characterization of a novel ginsenoside-hydrolyzing beta-glucosidase from Paecilomyces bainier sp. 229. Biosci Biotechnol Biochem 2008;72:352-359.

145. Yan Q, Zhou XW, Zhou W, Li XW, Feng MQ, Zhou P. Purification and properties of a novel beta-glucosidase, hydrolyzing ginsenoside $\mathrm{Rb}_{1}$ to $\mathrm{CK}$, from Paecilomyces bainier. J Microbiol Biotechnol 2008;18:1081-1089.

146. Park SY, Bae EA, Sung JH, Lee SK, Kim DH. Purification and characterization of ginsenoside $\mathrm{Rb}_{1}$-metabolizing beta-glucosidase from Fusobacterium K-60, a human intestinal anaerobic bacterium. Biosci Biotechnol Biochem 2001;65:1163-1169.

147. Yu H, Zhang C, Lu M, Sun F, Fu Y, Jin F. Purification and characterization of new special ginsenosidase hydrolyzing multi-glycisides of protopanaxadiol ginsenosides, ginsenosidase type I. Chem Pharm Bull (Tokyo) 2007;55:231-235.

148. Su JH, Xu JH, Lu WY, Lin GQ. Enzymatic transformation of ginsenoside $\mathrm{Rg}_{3}$ to $\mathrm{Rh}_{2}$ using newly isolated Fusarium proliferatum ECU 2042. J Mol Catal B Enzym 2006;38:113-118.

149. Bae EA, Choo MK, Park EK, Park SY, Shin HY, Kim $\mathrm{DH}$. Metabolism of ginsenoside R(c) by human intestinal bacteria and its related antiallergic activity. Biol Pharm Bull 2002;25:743-747.

150. Bae EA, Shin JE, Kim DH. Metabolism of ginsenoside Re by human intestinal microflora and its estrogenic effect. Biol Pharm Bull 2005;28:1903-1908.

151. Yu H, Gong J, Zhang C, Jin F. Purification and characterization of ginsenoside-alpha-L-rhamnosidase. Chem Pharm Bull (Tokyo) 2002;50:175-178.

152. Ruan CC, Zhang H, Zhang LX, Liu Z, Sun GZ, Lei J, Qin YX, Zheng YN, Li X, Pan HY. Biotransformation of ginsenoside $\mathrm{Rf}$ to $\mathrm{Rh}_{1}$ by recombinant beta-glucosidase. Molecules 2009;14:2043-2048. 